\title{
Characteristics of male Spot-bellied Bobwhite (Colinus leucopogon) song during territory establishment
}

\author{
Luis Sandoval · Gilbert Barrantes
}

Received: 2 January 2011/Revised: 3 August 2011/Accepted: 18 October 2011

(C) Dt. Ornithologen-Gesellschaft e.V. 2011

\begin{abstract}
In song-learning birds, male song shows a large inter-individual variation that frequently plays an important role in intra- and inter-sexual selection. In other bird groups, such as Galliformes, song learning is absent, and inter-individual song variation is small and expected to play a minor, if any, role in sexual contexts. In the Spot-bellied Bobwhite (Colinus leucopogon) we found that many males have a unique set of song features, and our results suggest that female mate choice in this species is based in part on male song traits. Most paired males in our study had longer songs. In addition, these males established territories in the middle of the breeding season, soon after the onset of the rainy season when increases in herbaceous cover and food resources would likely increase offspring and adult survival.
\end{abstract}

Keywords Galliformes - Reproductive season - Song variation $\cdot$ Spot-bellied Bobwhite $\cdot$ Territory characteristics

\section{Zusammenfassung}

\section{Gesangsmerkmale männlicher Fleckenwachteln (Colinus leucopogon) während der Reviergründung}

Bei Vogelarten, die Gesangslernen zeigen, weist der Gesang der Männchen eine große individuelle Variation auf,

Communicated by F. Bairlein.

L. Sandoval · G. Barrantes

Escuela de Biología, Universidad de Costa Rica,

Montes de Oca, Costa Rica

L. Sandoval $(\bowtie)$

Department of Biological Sciences, University of Windsor,

401 Sunset Avenue, Windsor, ON N9B 3P4, Canada

e-mail: biosandoval@hotmail.com welche häufig eine wichtige Rolle bei der intra- und intersexuellen Selektion spielt. Andere Vogelgruppen wie die Hühnervögel (Galliformes) lernen keine Gesänge; die individuelle Variation der Gesänge ist hier gering und spielt zwischen den Geschlechtern vermutlich kaum eine Rolle. Bei der Fleckenwachtel (Colinus leucopogon) besitzen dagegen viele Männchen ein individuelles Gesangsrepertoire. Die Ergebnisse dieser Studie weisen darauf hin, dass bei dieser Art die Weibchen ihren Partner zum Teil nach Gesangsmerkmalen wählen. Die meisten verpaarten Männchen hatten längere Gesangsstrophen. Außerdem besetzten diese Männchen ihre Reviere mitten in der Brutsaison, wenn kurz nach dem Beginn der Regenzeit die Zunahme der Krautschicht und der Nahrungsverfügbarkeit die Überlebenswahrscheinlichkeit von Jung- und Altvögeln erhöht.

\section{Introduction}

In song-learning birds, male song is often extremely variable, and in many species males have large repertories, with each individual often having a unique array of song types (Cicero and Benowitz-Fredericks 2000; Kipper et al. 2006). Male song types may vary in structural (e.g., number and elements arrangement) and acoustic characteristics (e.g., frequency range) among individuals of the same population (Kroosdma et al. 2002; Barrantes et al. 2008). Large repertoires and individual song arrays in song-learning birds apparently evolved through sexual selection by intra-sexual competition and female choice (Peek 1972; Smith 1979; Fedy and Stutchbury 2005; Walcott et al. 2006), and in many species females assess the quality of their potential mates via song (Capp 1992; 
Andersson 1994; Goodson and Adkins-Regan 1997; Ballentine et al. 2003; King et al. 2003; Dolby et al. 2005; Garamszegi et al. 2005; Hosoi et al. 2005; Spencer et al. 2005; Tomaszycki and Adkins-Regan 2005; Kipper et al. 2006; Ballentine 2009).

Male song plays an important role in establishing and defending territories in numerous song-learning birds (Krebs et al. 1978; Morse 1980; Beecher et al. 1994; Atkinson 1997; Gil and Gahr 2002). In many of these species, males with higher vocalization rates (Alatalo et al. 1990) and with a higher number of elements in their songs (Kipper et al. 2006) establish their territories and pair with females sooner than males with lower quality songs. By establishing territories early in the breeding season, males are able to increase the probability of selecting a better territory, resulting in higher reproductive success (Catchpole 1980; Eens et al. 1991; Lozano et al. 1995).

In the members of the Phasianidae and Meleagridae families (Galliformes) that have been studied to date, male song plays little or no role in intra- or inter-sexual selection (Vehrencamp et al. 1989; Beani and Dessi-Fulgheri 1995). Instead, body parts (e.g., combs, tail length), body size, and visual displays, all of which vary among males, are more often involved in male-male competition and female choice (Vehrencamp et al. 1989; Zuk et al. 1990; Alatalo et al. 1991; Holder and Montgomerie 1993; Zahavi and Zahavi 1997). There are, however, exceptions within the Galliformes, including a number of tetraonids (grouse family), in which acoustic signals are used in conjunction with visual signals in male-male competition and female choice contexts (Wiley 1974; Gibson and Bradbury 1985; Vehrencamp et al. 1989), and the Grey Partridge, in which females select males with higher pre-choice song rates (Beani and Dessi-Fulgheri 1995).

Among Galliformes, species of the neotropical woodquail family Odontophoridae have only minor differences in plumage, body size, and crests between sexes (Carroll 1994; Madge and McGowan 2002). Neotropical odontophorid species inhabit either mature forests or dense secondary growth areas where visual contact may be difficult, and acoustic communication becomes relatively more important (Hale 2006a, b; Sandoval 2009, 2011a). In some species of this family, such as the Northern Bobwhite, Crested Bobwhite, California Quail, and Scaled Quail, males sing frequently during the breeding season (Stokes 1967; Brennan 1999; Calkins et al. 1999; Dabbert et al. 2009; Pérez 2000; Sandoval 2008, 2011b), suggesting that male song may play a role in intra-sexual competition and female choice in these birds.

Our study species is the Spot-bellied Bobwhite (Colinus leucopogon: Odontophoridae), a terrestrial species that occurs in dense, secondary growth areas and abandoned coffee plantations. During the non-breeding period, individuals of both sexes form coveys of up to 20 individuals (Sandoval 2011b). These coveys disband prior to the breeding season (March-October) and soon after, males begin to sing at ground level or from low perches above the ground. This is an exclusive male behavior that signals the beginning of the breeding season and whose function is possibly to establish territories and attract females (Leber 1975; Sandoval 2008, 2011a). Males cease singing after pairing and then initiate the searching of a nesting site (Sandoval 2008, 2011a). The egg-laying period spans from 10 to 15 days, depending on egg number, followed by a 21- to 23-day incubation period (Sandoval 2011b). Males lack extravagant morphological traits and are socially monogamous during the breeding season (Leber 1975; Madge and McGowan 2002; Sandoval 2011a, b). After breeding, both parents contribute to offspring care (Sandoval 2008, 2009). In our study we addressed two questions: Is there variation in song in the Spot-bellied Bobwhite? And if songs are variable, is this variation associated with territory establishment and female choice? We predicted that: (1) if male song plays an important role in territory establishment and female choice, then songs should vary among males; (2) if male pairing success is correlated with some particular song characteristic, then male song could reflect male quality. We additionally measured characteristics of males' territories and associated these with pairing success.

\section{Methods}

\section{Study area}

We conducted this study between March and October 2005 and 2006, at Getsemaní, Heredia province, Costa Rica $\left(10^{\circ} 01^{\prime} \mathrm{N}, 84^{\circ} 06^{\prime} \mathrm{W} ; 1,300 \mathrm{~m}\right.$ a.s.l. $)$. Annual rainfall averages 2,000 $\mathrm{mm}$ with a dry season from December to April (Sandoval 2011a). The 30-ha study area comprises pastures with isolated trees (18 ha) and shade coffee plantations (12 ha). We recorded adult male Spot-bellied Bobwhite songs within $50 \mathrm{~m}$ of a $3-\mathrm{km}$ transect from 0700 to 1100 hours every week during the study period, alternating the starting point of the transect. Singing males were considered to be territorial if (1) they were observed singing continually for at least $5 \mathrm{~min}$ without abandoning an area of a 5-m radius around the main singing perch (the perch most frequently used by a singing male) and (2) the same singing perches were used for 1-9 consecutive weeks. In contrast, singing non-territorial males moved from perch to perch between song bouts and were not observed at the same perches from 1 week to the next. We arbitrarily defined a male's territory as a circle of radius $25 \mathrm{~m}$ around the main singing perch. This is the distance 
Fig. 1 Spectrograms of two singing Spot-bellied Bobwhite (Colinus leucopogon) males. The first male (a) has two elements in his song, and the second male (b) has three elements due to repetition of the first element. Part of the silent time between two consecutive songs was eliminated to show the two songs of each male. $H F$ High frequency, $L F$ low frequency, $\Delta T$ song duration
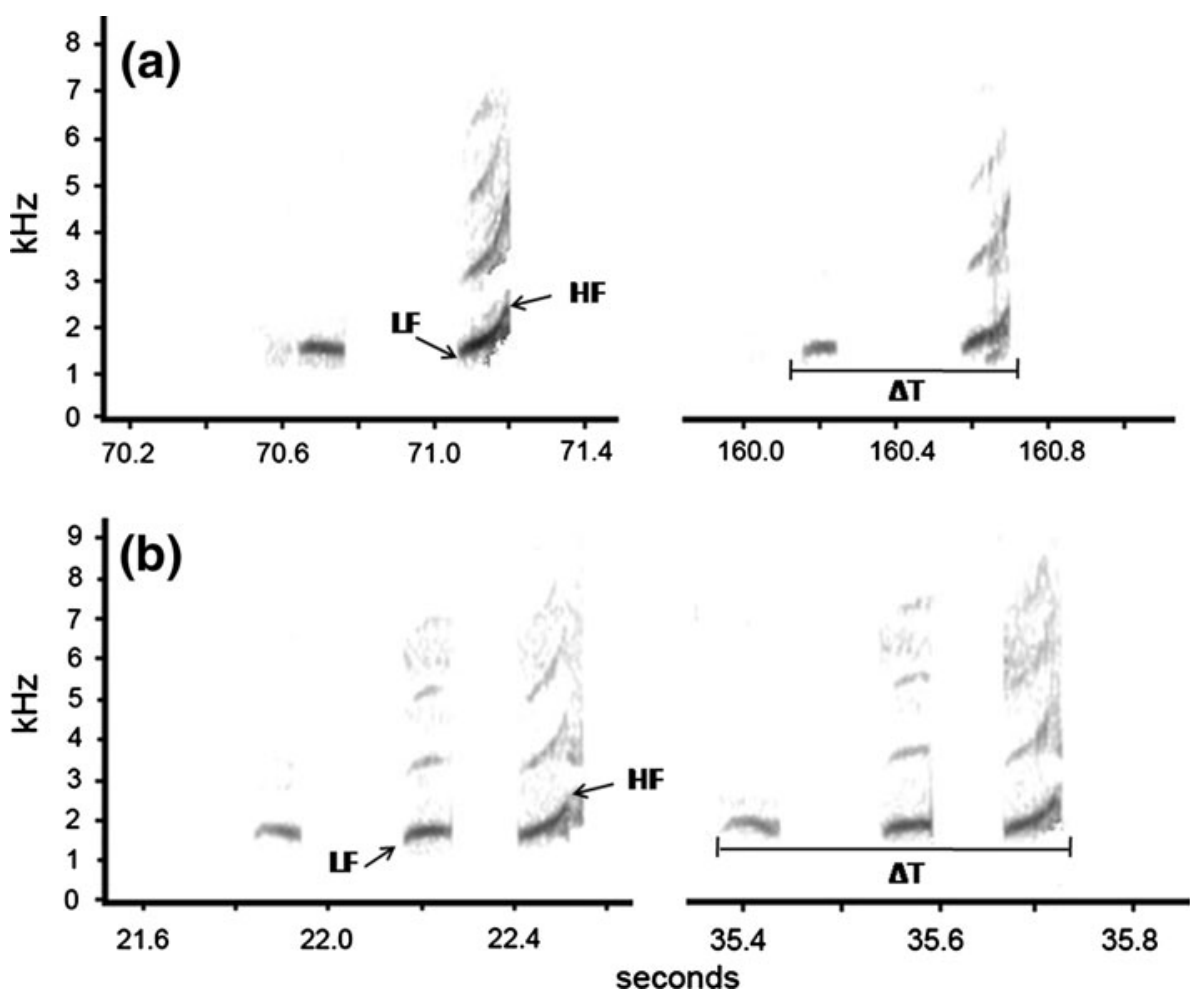

between the two closest main singing perches of two territorial males we observed in this study and is similar to the distance between nearby males reported by Leber (1975).

Males were not banded, but if a male was using the same singing perches during subsequent weeks we considered it as the same individual, based on the high improbability that different males would use exactly the same perch week after week in a single territory (Barrantes et al. 2008; Fitzsimmons et al. 2008). After territory establishment, we searched for a female within each male's territory for 30-40 min each week for up to 4 weeks. A male was considered paired if he was observed with a female in his territory and was no longer singing. If a male was not seen or heard in his territory for three consecutive weeks after initial territory establishment, we assumed that the male had abandoned the territory and therefore placed him in the unpaired group for statistical analyses. This last assumption may have resulted in an overestimation of the number of unpaired males.

\section{Song measurements}

We recorded all singing Spot-bellied Bobwhite males in the study area each year. Each male was recorded only the first week that he was heard singing; all recordings were conducted under a clear sky or under partially cloudy conditions. Since males were not individually marked, this sampling procedure reduces the probability of recording the same male more than once in the same breeding season, although it does not reduce the probability of recording the same male between breeding seasons. To prevent the pseudoreplication of males across years, we analyzed each year independently. The song of males is stereotyped and consists of two or three different elements (Fig. 1). Each singing male was recorded for $5 \mathrm{~min}$ from a distance of 5-15 m, using a tape recorder (TCM-5000EV; Sony, Tokyo, Japan) and a ME 66 shotgun microphone (Sennheiser, Hanover, Germany). From each 5-min-long song bout, we randomly selected five high-quality songs (little reverberation) for analysis. For species with innate songs or with little variation in their songs, it has been shown that a small number of randomly selected songs are sufficient to reveal individual patterns of song features (Seddon 2005; Barrantes et al. 2008; Araya-Ajoy et al. 2009). We tested this assumption in a two-sample $t$ test in which all song features analyzed in the five songs selected randomly (small sample) were compared against the total songs recorded for those birds with a sufficient sample size ( $\geq 10$ songs recorded; $n=14$ ); no significant differences in any of the variables were detected ( $P>0.12$ for all comparisons). For those males with five or fewer recorded songs, all songs were included in the analysis (one male had 4 songs, two had 2 songs, and one had only 1 song). Songs were digitalized at a sampling rate of $44,100 \mathrm{~Hz}$ and a resolution of 16 bits with the program Cool Edit 2000 ver. 1.0 (Johnston 1999); subsequent sound analysis was conducted using Raven 1.2 (Charif et al. 2004). From each song spectrogram, we measured the following variables: low frequency 
(LF), high frequency (HF), frequency bandwidth $(\Delta F$; difference between HF and LF), maximum frequency (MF; frequency that carry the highest energy), song duration $(\Delta T)$, and number of elements (Fig. 1). All recordings were deposited in the Laboratorio de Bioacústica, Escuela de Biología, Universidad de Costa Rica.

\section{Territory features}

To compare territory characteristics among males, we counted the number of potential singing perches (e.g., logs, rocks, and branches with a similar height and structural conditions to those used when males sing) and estimated the percentage cover of ramets of tall grass that were at least $25 \mathrm{~cm}$ tall and $30 \mathrm{~cm}$ in diameter, which represented the potential nesting area within each territory (Leber 1975; Stiles and Skutch 1989). We recorded these data during the first week a male was observed in his territory. Territories were not reused during the same breeding seasons, but in the second study year, six males established territories that overlapped with territories that had been occupied the previous season.

\section{Statistical analyses}

The within $(\mathrm{CVw})$ and between $(\mathrm{CVb})$ individual coefficient of variation was calculated each year for the acoustic and temporal variables of male songs $(n=15$ males per year). Student $t$ tests were used to compare the $\mathrm{CVw}$ and $\mathrm{CVb}$ means for each variable; $\alpha=0.008$ was used to reject null hypotheses due to multiple comparisons. We also calculated the $\mathrm{CVb} / \mathrm{CVw}$ ratio; a ratio $>1$ indicates that variation is larger between than within individuals, and a ratio $>2$ indicates that the variable analyzed may possess unique cues for individual recognition, as proposed Vignal et al. (2008) and Seddon and Tobias (2010).

A forward stepwise discriminant function analysis (DFA) was conducted to analyze the variation in acoustic and temporal song variables between males for each year $(n=15$ males per year). We cross-validated each model to estimate the percentage of correct classifications produced by the DFA at each step using a Jackknife approach (Systat 11; Systat Software). The forward stepwise option excluded from the analysis those highly correlated variables that did not explain the between-individual variance, and crossvalidation allowed us to obtain the model that best separated individuals. To analyze the relationship between acoustic and temporal characteristics of male song and time of territory establishment, we grouped males by month (grouping variable) and then conducted a DFA including only the five variables that best separated males based on their song characteristics. In addition, we calculated the centroid for each month using the first two canonical variables and compared them between years. DFAs were calculated by year, rather than combining both years, to reduce pseudoreplication of males across years. We also compared territory characteristics between paired and unpaired males each year using the Kruskal-Wallis nonparametric analysis of variance (ANOVA).

The Akaike information criterion (AIC) was used to determine which model(s) constructed with $\Delta T, \mathrm{MF}$, and LF (the three variables that best separated male songs and contributed to separating males by month) best predict pairing success in males $(n=6$ paired vs. $n=9$ nonpaired males from each year). We used male pairing success (yes or no) as dependent variable and the song features as independent variables to construct the models. We report the AIC value, and used the change in the small-samplesize corrected version $\left(\Delta \mathrm{AIC}_{\mathrm{c}}\right)$ for model selection (Burnham et al. 2011); models with $\Delta \mathrm{AIC}_{\mathrm{c}}$ values differing by $\leq 2$ were considered to be equally parsimonious with the best supported model $\left(\Delta \mathrm{AIC}_{\mathrm{c}}=0\right)$. We also calculated the $\mathrm{AIC}_{\mathrm{w}}$, values which represent the model weight and are equivalent to the variance that explains each model (Richards et al. 2011).

\section{Results}

Songs from 15 males were recorded in each breeding season. In 2005, males established territories (i.e., began to sing) from March to September, with more males establishing their territories in August $(n=4)$. In 2006, males began to established territories from April through August, with more males establishing their territories in May $(n=5)$. Male song in this species has two or three harmonic elements (Fig. 1a, b). Combining data from both years, we found that five males had only two elements in their songs, 18 males had three elements in all songs, and seven males had three elements in a portion of their songs ( 3 males in $20 \%$ of songs; 2 males in $80 \%$ of songs; 1 male in $60 \%$ of songs; 1 male in $50 \%$ of songs).

The coefficient of variation between males $(\mathrm{CVb})$ was significantly higher than within males $(\mathrm{CVw})$ for two of the six variables (LF and MF) in 2005 and for three variables ( $\Delta T, \mathrm{LF}$, and MF) in 2006 (Table 1). In 2005, the CVb/ $\mathrm{CVW}$ ratios were $>2$ for only $\mathrm{LF}$ and MF; in 2006, the $\mathrm{CVb} / \mathrm{CVw}$ ratios were $>2$ for $\Delta T, \mathrm{LF}$, and MF (Table 1).

In addition, a combination of five variables (number of elements, song duration, and LF, HF, MF) explained a significant proportion of between-male song variation in 2005 and 2006 (2005: Wilks' $\Lambda=0.002, F_{70,237}=9.26$, $P<0.001 ;$ 2006: Wilks' $\Lambda=0.007, \quad F_{70,218}=9.26$, $P<0.001)$. These variables correctly classified $62 \%$ of all male songs in 2005 and 50\% in 2006. The same acoustic and temporal variables significantly explained a large 
Table 1 Coefficient of variation between and within males for six acoustic and temporal variables of the Spotbellied Bobwhite male song

* Song measurements that are significant according to $\mathrm{CVb}$ and $\mathrm{CVw}$ with an $\alpha=0.008$ to reject null hypotheses due to multiple comparisons

CVw, CVb, Within and between individual coefficient of variation, respectively

${ }^{\text {a }}$ Degrees of freedom for $t$ test are 18 in all cases

\begin{tabular}{lccccc}
\hline Variable & $\mathrm{CVb}$ & $\mathrm{CVw}$ & $\mathrm{CVw} / \mathrm{CVb}$ ratio & $t$ test $^{\mathrm{a}}$ & $P$ \\
\hline 2005 & & & & & \\
$\quad$ Duration & 0.14 & 0.09 & 1.56 & 1.64 & 0.01 \\
Low frequency & 0.23 & 0.03 & $8.01^{*}$ & 6.28 & $0.003^{*}$ \\
High frequency & 0.05 & 0.06 & 0.90 & -0.39 & 0.70 \\
Frequency bandwidth & 0.19 & 0.12 & 1.65 & 2.63 & 0.02 \\
Maximum frequency & 0.36 & 0.02 & $16.48^{*}$ & 17.14 & $<0.001^{*}$ \\
Elements & 0.04 & 0.04 & 1.02 & 0.04 & 0.97 \\
2006 & & & & 3.17 & $0.006^{*}$ \\
Duration & 0.19 & 0.09 & $2.06^{*}$ & 16.96 & $<0.001^{*}$ \\
Low frequency & 0.24 & 0.02 & $12.7^{*}$ & -2.74 & 0.01 \\
High frequency & 0.04 & 0.10 & 0.45 & -2.92 & 0.009 \\
Frequency change & 0.08 & 0.23 & 0.35 & 2.52 & $0.006^{*}$ \\
Maximum frequency & 0.18 & 0.01 & $13.52^{*}$ & -1.21 & 0.25 \\
Elements & 0.03 & 0.06 & 0.45 & & \\
\hline
\end{tabular}

Considering the three variables that have a major effect in separating males ( $\Delta T, \mathrm{MF}, \mathrm{LF}$; based on $\mathrm{CVb} / \mathrm{CVw}$ ratio), successful males had longer songs (successful: mean $0.83 \mathrm{~s}$, SD 0.03; unsuccessful: mean $0.75 \mathrm{~s}$, SD $0.03 ; F_{29,102}=$ $10.90, P<0.001$ ), higher MF (successful: mean $1,792.5 \mathrm{~Hz}$, SD 17.2; unsuccessful: mean $1,755.2 \mathrm{~Hz}$, SD $16.2 ; F_{29,102}=$ 21.46, $P<0.001$ ), and lower LF (successful: mean $1,359.1 \mathrm{~Hz}$, SD 7.2; unsuccessful: mean $1,367.8 \mathrm{~Hz}$, SD 12.6; $F_{29,102}=$ $8.14, P<0.001)$ than males that were unsuccessful in pairing with a female. However, from the set of models constructed with these three variables, the model that included only $\Delta T$ best predicted male pairing success in each year (Table 2 ). In contrast, the models constructed with LF, MF, and a combination of the three song features had very little support.
Fig. 2 Mean centroid of the first two canonical functions obtained with the discriminant function analysis (DFA) of male Spot-bellied Bobwhite song characteristics (LF, HF, maximum frequency, $\Delta T$, and number of song elements) by month of the breeding season

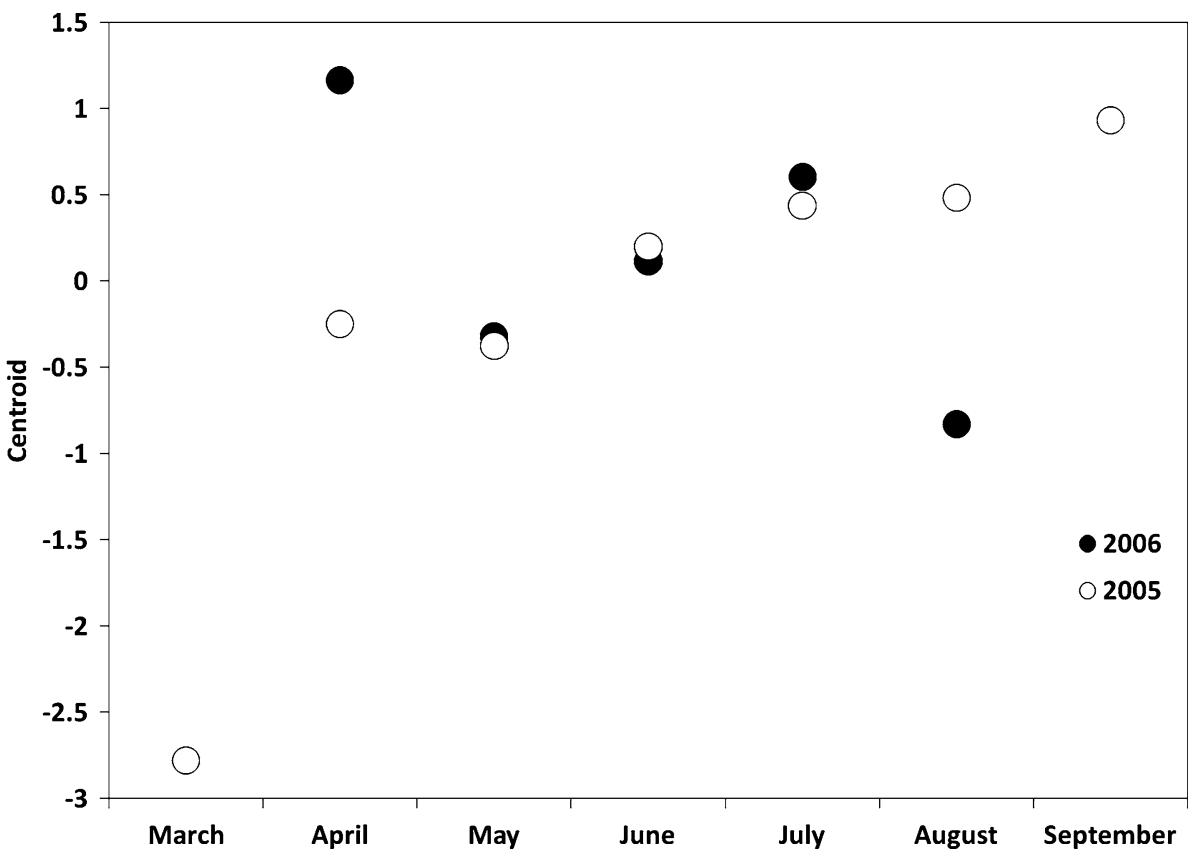


Table 2 Set of models constructed with different combinations of three acoustic variables (song duration, maximum frequency, low frequency) to predict the mating success of Spot-bellied Bobwhite males based on the AIC method by year

$\Delta \mathrm{AIC}_{\mathrm{c}}$, small-sample-size corrected version of the Akaike information criterion (AIC), i.e., the difference between the current AIC model score and the model with the lowest AIC score; $\mathrm{AIC}_{\mathrm{w}}$, the model weight; $\Delta T$, song duration; $L F$, low frequency; $\mathrm{MF}$, maximum frequency

Bold face values correspond to the best models according to the AIC method

\begin{tabular}{lllccc}
\hline Model & Parameters & $n$ & AIC & $\Delta \mathrm{AIC}_{\mathrm{c}}$ & AIC $_{\mathrm{w}}$ \\
\hline 2005 & & & & & \\
$\boldsymbol{\Delta} \boldsymbol{T}$ & $\mathbf{3}$ & $\mathbf{1 5}$ & $\mathbf{- 2 8 . 6 9}$ & $\mathbf{0}$ & $\mathbf{0 . 9 9}$ \\
LF & 3 & 15 & -6.97 & 21.72 & $<0.001$ \\
$\Delta T+\mathrm{LF}$ & 4 & 15 & -5.07 & 25.44 & $<0.001$ \\
MF & 3 & 15 & 5.73 & 34.42 & $<0.001$ \\
LF + MF & 4 & 15 & 6.44 & 36.95 & $<0.001$ \\
$\Delta T+$ MF & 4 & 15 & 6.63 & 37.13 & $<0.001$ \\
All & 5 & 15 & 7.31 & 40.48 & $<0.001$ \\
2006 & & & & & \\
$\Delta \boldsymbol{L}$ & $\mathbf{3}$ & $\mathbf{1 5}$ & $\mathbf{- 1 4 . 8}$ & $\mathbf{0}$ & $\mathbf{0 . 9 9}$ \\
LF & 3 & 15 & 9.97 & 24.77 & $<0.001$ \\
$\Delta T+$ LF & 4 & 15 & 11.75 & 28.37 & $<0.001$ \\
MF & 3 & 15 & 12.35 & 27.14 & $<0.001$ \\
LF + MF & 4 & 15 & 15.42 & 32.04 & $<0.001$ \\
$\Delta T+$ MF & 4 & 15 & 22.31 & 38.92 & $<0.001$ \\
All & 5 & 15 & 25.82 & 45.11 & $<0.001$ \\
\hline
\end{tabular}

\section{Discussion}

In Galliformes, body size, plumage, coloration, spurs, comb size, and coloration of combs have been demonstrated to play an important role in inter- and intra-sexual selection (Zuk et al. 1990; Alatalo et al. 1991; Holder and Montgomerie 1993; Zahavi and Zahavi 1997; Hagelin 2002), while vocalizations have been thought to be relatively unimportant (Vehrencamp et al. 1989; Leonard and Horn 1995; Wilson et al. 2008). Nevertheless, our findings show that temporal and acoustic characteristics of the song did vary among Spot-bellied Bobwhite males and that those males possessing certain variants were more successful in pairing with females than males without those variants. The role of male song in courtship and territorial interactions in this species is possibly associated with the cryptic coloration, limited sexual dimorphism, and often secretive behavior of the species comprising family Odontophoridae. This neotropical group of birds inhabits dense secondary growth vegetation and the understory of mature forests where vocalizations likely play an important role in different communication contexts (Hale 2006b; Sandoval 2009, 2011a).

Sexual selection theory predicts that females should select males based on traits that indicate quality and vary between high- and low-quality males (Zuk et al. 1990; Petrie et al. 1991; Andersson 1994). Male song traits are often used by females of many song-learning birds to evaluate male quality and directly influence female choice (Dolby et al. 2005; Kipper et al. 2006; Mennill et al. 2006). In the Spot-bellied Bobwhite of our study, females paired chiefly with males that had longer songs. The capability to produce longer songs has been demonstrated to increase energetic cost in other birds and seems to play an important role in mating success (Lambrechts 1996; Smith 1996; Oberweger and Goller 2001; Gil and Gahr 2002; Collins 2004). Hence, it is possible that female sexual selection in Spot-bellied Bobwhites may operate on traits that demonstrate variation and, therefore, might be distinctive between males of high and low quality. Our study is the first to suggest that song traits may be used by female odontophorids in mate selection.

Most of the males in our study established territories and paired after the beginning of the breeding season (March), contrary to many other bird species in which the probability of pairing is higher for males that establish territories at the beginning of the breeding season (Howard 1974; Capp 1992; Hoi-Leitner et al. 1995; Kipper et al. 2006). Spot-bellied Bobwhite breeding is likely timed to coincide with the availability of better nesting sites and food resources and maximum offspring protection (Sandoval 2011a), suggesting that female choice is likely based upon a combination of male song traits, time of territory establishment, and territory quality. This species constructs nests at ground level within extremely dense mats of tall grass and other herbaceous vegetation (Leber 1975; Stiles and Skutch 1989; Sandoval 2011b), which also provides offspring and adults with a refuge against predators (Sandoval 2009). The rainy season begins in May, and as tall grasses and other plants grow, there is an increase in the availability of nesting sites, cover for offspring and adults, and food resources, such as arthropods and seeds (Leber 1975; Lusk et al. 2001; Sandoval 2011a). Although we estimated the extent of the potential nesting habitat within each territory, we did not measure the quality or number of nesting places themselves. 
One limitation associated with our results is that territory establishment and female choice may not be exclusively based on song features. We did not measure morphological features, such as body size and plumage color, nor visual displays that may either be correlated with acoustical traits or act in concert with acoustical traits and thus influence female choice and male-male competition (Gibson and Bradbury 1985). We also did not measure other territorial features (e.g., fine nesting sites features) that may also be important during female choice. Further experimental studies are necessary to examine the role of different signals on female choice and male-male competition within a multimodal signaling context in this species (Hebets and Papaj 2005).

To summarize, the results of this study demonstrate that temporal and acoustic characteristics of male Spot-bellied Bobwhite song vary within a population. This variation, possibly driven by sexual selection, seems to allow females to select males with a particular set of song and territorial traits. Most males established their territories and paired with females after the beginning of the breeding season. Breeding during this period likely increases the probability of breeding success since it corresponds with the onset of the rainy season when suitable nesting sites, refuge sites, and food availability increase.

Acknowledgments We thank William Eberhard, Johel Chaves, Jessica Eberhard, Edgardo Arévalo, Franz Bairlein, and two anonymous reviewers for helpful comments on previous versions of the manuscript. Financial support was provided by the Idea Wild and the Vicerrectoría de Investigación, Universidad de Costa Rica.

\section{References}

Alatalo R, Glynn C, Lundberg A (1990) Singing rate and female attraction in the pied flycatcher: an experiment. Anim Behav 39:601-603

Alatalo R, Höglund J, Lundberg A (1991) Lekking in the black grouse a test of male viability. Nature 352:155-156

Andersson M (1994) Sexual selection. Princeton University Press, Princeton

Araya-Ajoy Y, Chaves-Campos J, Kalko EKV, DeWoody JA (2009) High-pitched notes during vocal contests signal genetic diversity in ocellated ant birds. Plos One 4:e8137. doi:10.1371/journal. pone. 0008137

Atkinson E (1997) Singing for your supper: acoustical luring of avian prey by northern shrikes. Condor 99:203-206

Ballentine B (2009) The ability to perform physically challenging songs predicts age and size in male swamp sparrows, Melospiza georgiana. Anim Behav 77:973-978

Ballentine B, Badyaev A, Hill GE (2003) Changes in song complexity correspond to periods of female fertility in blue grosbeaks (Guiraca caerulea). Ethology 109:55-66

Barrantes G, Sánchez C, Hilje B, Jaffé R (2008) Male song variation of green violetear (Colibri thalassinus) in the Talamanca mountain range, Costa Rica. Wilson J Ornithol 120:519-524
Beani L, Dessi-Fulgheri F (1995) Mate choice in the grey partridge, Perdix perdix: role of physical and behavioural traits. Anim Behav 49:347-356

Beecher M, Campbell E, Stoddard P (1994) Correlation of song learning and territory establishment strategies in the song sparrow. Proc Nat Acad Sci USA 91:1450-1454

Brennan LA (1999) Northern Bobwhite (Colinus virginianus). In: Poole A, Gill F (eds) The birds of North America, no. 397. The Birds of North America, Inc, Philadelphia. doi:10.2173/bna.397

Burnham KP, Anderson DR, Huyvaert KP (2011) AIC model selection and mutimodle inference in behavioural ecology: some background, observations, and comparisons. Behav Ecol Sociobiol 65:23-35

Calkins JD, Hagelin JC, Lott DF (1999) California quail (Callipepla californica). In: Poole A, Gill F (eds) The birds of North America, no. 473. The Birds of North America, Inc, Philadelphia. doi: $10.2173 /$ bna. 473

Capp M (1992) Test of the function of the song repertoire in bobolinks. Condor 94:468-479

Carroll J (1994) Family Odontophoridae (new world quail). In: del Hoyo J, Elliot A, Sargatal J (eds) Handbook birds of the world, vol 2: New World vultures to guineafowl. Lynx Edicions, Madrid, pp 412-433

Catchpole CK (1980) Sexual selection and the evolution of complex songs among European warblers of the genus Acrocephalus. Behaviour 74:149-166

Charif R, Clark C, Fristrup K (2004) Raven 1.2 user's manual. Cornell Laboratory of Ornithology, Ithaca

Cicero C, Benowitz-Fredericks M (2000) Song types and variation in insular population of Lincoln's sparrow (Melospiza lincolnii), and comparisons with other Melospiza. Auk 117:52-64

Collins S (2004) Vocal fighting and flirting: the functions of birdsong. In: Marler P, Slabbekoorn H (eds) Nature's music, the science of birdsong. Elsevier, San Diego, pp 40-79

Dabbert CB, Pleasant G, Schemnitz SD (2009) Scaled quail (Callipepla squamata). In: Poole A, Gill F (eds) The birds of North America, no. 106. The Birds of North America, Inc, Philadelphia. doi:10.2173/bna.106

Dolby AS, Clarkson CE, Haas ET, Miller JK, Havens LE, Cox BK (2005) Do song-phrase production rate and song versatility honestly communicate male parental quality in the gray catbird? J Field Ornithol 76:287-292

Eens M, Pinxten R, Verheyen RF (1991) Male song as a cue for mate choice in the European starling. Behaviour 116:210-238

Fedy B, Stutchbury B (2005) Territory defence in tropical birds: are females as aggressive as males? Behav Ecol Sociobiol 58:414-422

Fitzsimmons LP, Barker NK, Mennill DJ (2008) Individual variation and lek-based vocal distinctiveness in songs of the screaming piha (Lipagus vociferans), a suboscine songbird. Auk 125:

908-914

Garamszegi LZ, Heylen D, Møller AP, Eens M, de Lope F (2005) Age-dependent health status and song characteristics in the barn swallow. Behav Ecol 16:580-591

Gibson R, Bradbury JW (1985) Sexual selection in lekking sage grouse: phenotypic correlates of male mating success. Behav Ecol Sociobiol 18:117-123

Gil D, Gahr M (2002) The honesty of bird song: multiple constraints for multiple traits. Trends Ecol Evol 17:133-141

Goodson JL, Adkins-Regan E (1997) Playback of crows of male Japanese quail elicits female phonotaxis. Condor 99:990-993

Hagelin J (2002) The kinds of traits involved in male-male competition: a comparison of plumage, behaviour, and body size quail. Behav Ecol 13:32-41 
Hale A (2006a) The structure, context and functions of group singing in black-breasted wood-quail (Odontophorus leucolaemus). Behaviour 143:511-533

Hale A (2006b) Group living in the black-breasted wood-quail and the use of playbacks as a survey technique. Condor 108:107-119

Hebets EA, Papaj DA (2005) Complex signal function: developing a framework of testable hypotheses. Behav Ecol Sociobiol $57: 197-214$

Hoi-Leitner M, Nechtelberger H, Hoi H (1995) Song rate as a signal for nest site quality in blackcaps (Sylvia atricapilla). Behav Ecol Sociobiol 37:399-405

Holder K, Montgomerie R (1993) Context and consequences of comb displays by male rock ptarmigan. Anim Behav 45:457-470

Hosoi SA, Rothstein SI, O'Loghlen AL (2005) Sexual preferences of female brown-headed cowbirds (Molothrus ater) for perched song repertoires. Auk 122:82-93

Howard R (1974) The influence of sexual selection and interspecific competition on mockingbird song (Mimus polyglottos). Evolution 28:428-438

Johnston D (1999) Cool edit 2000. Syntrillium Software Corp, Phoenix

King AP, West MJ, White DJ (2003) Female cowbird song perception: evidence for plasticity of preference. Ethology 109:865-877

Kipper S, Mundry R, Sommer C, Hultsch H, Todt D (2006) Song repertoire size is correlated with body measures and arrival date in common nightingales, Luscinia megarhynchos. Anim Behav 71:211-217

Krebs J, Ashcroft R, Webber M (1978) Song repertoires and territory defence in the great tit. Nature 271:539-542

Kroosdma D, Woods R, Goodwin E (2002) Falkand Island sedge wrens (Cistothorus platensis) imitate rather than improvise large song repertories. Auk 119:523-528

Lambrechts MM (1996) Organization of birdsong and constraints on perfomace. In: Kroodsma DE, Miller EH (eds) Ecology and evolution of acoustic communication in birds. Cornell University Press, Ithaca, pp 305-320

Leber K (1975) Notes on the life history of the spot-bellied bobwhite, Colinus leucopogon dickeyi, Conover. Brenesia 5:7-21

Leonard ML, Horn AG (1995) Crowing in relation to status roosters. Anim Behav 48:1283-1290

Lozano GA, Perreault S, Lemon RE (1995) Age, arrival date and reproductive success of male American redstarts Serophaga ruticilla. J Avian Biol 27:164-170

Lusk J, Guthery F, De Maso S (2001) Northern bobwhite (Colinus virginianus) abundance in relation to yearly weather and longterm climate patterns. Ecol Model 146:3-15

Madge S, McGowan P (2002) Pheasants, partridge and grouse. Princeton University Press, Princeton

Mennill DJ, Badayaev A, Jonart L, Hill G (2006) Male house finches with elaborate songs have higher reproductive performance. Ethology 112:174-180

Morse DH (1980) Behavioral mechanisms in ecology. Harvard University Press, Cambridge

Oberweger K, Goller F (2001) The metabolic cost of birdsong production. J Exp Biol 204:3379-3388

Peek F (1972) An experimental study of the territorial function of vocal and visual display in the male red-winged blackbird (Agelaius phoeniceus). Anim Behav 20:112-118

Pérez E (2000) Seasonal diet composition in the crested bobwhite in savannas of central-eastern Venezuela. Stud Neotrop Fauna Environ 35:91-99

Petrie M, Halliday T, Sanders C (1991) Peahens prefer peacocks with elaborate trains. Anim Behav 41:323-331
Richards SA, Whittingham MJ, Stephens PA (2011) Model selection and model averaging in behavioural ecology: the utility of the IT-AIC framework. Behav Ecol Sociobiol 65:77-89

Sandoval L (2008) Función del canto y el territorio en machos de la codorniz de monte Colinus leucopogon (Odontophoridae: Aves) durante el periodo reproductivo. PhD thesis. University of Costa Rica, San Pedro

Sandoval L (2009) Descripción del comportamiento de cuido parental en la Codorniz de Monte (Colinus leucopogon). Int J Galliformes Conserv 1:36-40

Sandoval L (2011a) Inicio de la época reproductiva y permanencia territorial en machos de Colinus leucopogon (Galliformes: Odontophoridae). Rev Biol Trop 59:363-372

Sandoval L (2011b) Crested Bobwhite (Colinus cristatus). In: Schulenberg TS (ed) Neotropical birds online. Cornell Lab of Ornithology, New York. Available at: http://neotropical.birds. cornell.edu/portal/species/overview?p_p_spp=85511. Accessed 10 May 2011

Seddon N (2005) Ecological adaptation and species recognition drives vocal evolution in neotropical suboscine birds. Evolution 59:200-215

Seddon N, Tobias JA (2010) Character displacement from the receiver's perspective: species and mate recognition despite convergent signals in suboscine birds. Proc R Soc B 277:24752483

Smith D (1979) Male singing ability and territory integrity in redwinged blackbird (Agelaius phoeniceus). Behaviour 68:193-206

Smith WJ (1996) Using interactive playback to study how songs and singing contribute to communication about behavior. In: Kroodsma DE, Miller EH (eds) Ecology and evolution of acoustic communication in birds. Cornell University Press, Ithaca, pp 377-397

Spencer KA, Whimpenny JH, Buchanan KL, Lovell PG, Goldsmith AR, Catchpole CK (2005) Developmental stress affects the attractiveness of male song and female choice in the zebra finch (Taeniopygia guttata). Behav Ecol Sociobiol 58:423-428

Stiles G, Skutch A (1989) Guide to the birds of Costa Rica. Cornell University Press, Ithaca

Stokes AW (1967) Behavior of the bobwhite, Colinus virginianus. Auk 84:1-33

Tomaszycki ML, Adkins-Regan E (2005) Experimental alteration of male song quality and output affects female mate choice and pair bond formation in zebra finches. Anim Behav 70:785-794

Vehrencamp S, Bradbury J, Gibson R (1989) The energetic cost of display in male sage grouse. Anim Behav 38:885-896

Vignal C, Mathevon N, Mottin S (2008) Materecognition by female zebra finch: analysis of individuality in male call and first investigations on female decoding process. Behav Proc 77:191198

Walcott C, Mager J, Piper W (2006) Changing territories, changing tunes: male loons, Gavia immer, change their vocalizations when they change territories. Anim Behav 71:673-683

Wiley RH (1974) Evolution of social organization and life history patterns among grouse (Aves: Tetraonidae). Q Rev Biol 49:201-227

Wilson DR, Bayly KL, Nelson XJ, Gillings M, Evans CS (2008) Alarm calling best predicts mating and reproductive success in ornamented male fowl, Gallus gallus. Anim Behav 76:543-554

Zahavi A, Zahavi A (1997) The handicap principle. A missing piece of Darwin's puzzle. Oxford University Press, Oxford

Zuk M, Johnson K, Thornhill R, Ligon D (1990) Mechanism of female choice in red jungle fowl. Evolution 44:477-485 